\title{
DEVELOPMENT OF E-MODULE BASED ON PROBLEM BASED LEARNING (PBL) IN HYDROCARBON MATERIAL
}

\author{
Tsurayya Zhafirah \\ Universitas Riau, Riau, Indonesia \\ Email: tsurayyazh20896@gmail.com \\ Maria Erna \\ Universitas Riau, Riau, Indonesia \\ Email: mariaerna@lecturer.unri.ac.id \\ R. Usman Rery \\ Universitas Riau, Riau, Indonesia \\ Email: rery1959@gmail.com
}

DOI: 10.35445/alishlah.v12.i2.263

Accepted: October $19^{\text {th }}, 2020$. Approved: November $9^{\text {th }}, 2020$

Published: December $30^{\text {th }}, 2020$

\begin{abstract}
This study aims to develop e-module based on Problem Based Learning (PBL) on hydrocarbon materials using the Kvisoft Flipbook Maker application. This research is a development research with 4-D development model. The data obtained came from 6 validators ( 3 material experts and 3 media experts), 4 chemistry teachers and 12 students from four high schools namely SMA Negeri 8 Pekanbaru, SMA Negeri 5 Pekanbaru, SMA Negeri 3 Pekanbaru and SMA IT AlFityah Pekanbaru. Data collection techniques used in the form of documentation and questionnaires. The data analysis technique is by calculating the percentage score of the validation assessment and user responses. The results showed that the e-module developed fulfilled very valid criteria with a percentage of $85.39 \%$ by material experts and $97.02 \%$ by media experts. The results of the chemistry teacher and student response test showed that the e-module developed fulfilled very practical criteria with a percentage of $92.60 \%$ by chemistry teachers and $89.60 \%$ by students.
\end{abstract}

Keywords: Development, E-Module, Problem Based Learning, Hydrocarbon

\section{PENGEMBANGAN E-MODUL BERBASIS PROBLEM BASED LEARNING (PBL) PADA MATERI HIDROKARBON}

\footnotetext{
Abstrak

Penelitian ini bertujuan untuk mengembangkan e-modul berbasis Problem Based Learning (PBL) pada materi hidrokarbon dengan menggunakan aplikasi Kvisoft
} 
Al-Ishlah: Jurnal Pendidikan - ISSN: 2087-949o (p); 2597-940X (e)

Vol. 12, No. 2(2020)

Flipbook Maker. Penelitian ini merupakan penelitian pengembangan dengan model pengembangan 4-D. Data yang diperoleh berasal dari 6 validator (3 ahli materi dan 3 ahli media), 4 guru kimia dan 12 peserta didik dari empat sekolah menengah atas yaitu SMA Negeri 8 Pekanbaru, SMA Negeri 5 Pekanbaru, SMA Negeri 3 Pekanbaru dan SMA IT Al-Fityah Pekanbaru. Teknik pengumpulan data yang digunakan dalam bentuk dokumentasi dan kuesioner. Teknik analisis data yaitu dengan cara menghitung skor persentase penilaian validasi dan respon pengguna. Hasil penelitian menunjukkan bahwa e-modul yang dikembangkan memenuhi kriteria sangat valid dengan persentase $85,39 \%$ oleh ahli materi dan 97,02\% oleh ahli media. Hasil uji respon guru kimia dan peserta didik menunjukkan bahwa e-modul yang dikembangkan memenuhi kriteria sangat praktis dengan persentase 92,60\% oleh guru kimia dan $89,60 \%$ oleh peserta didik.

Kata Kunci: Pengembangan, E-Modul, Problem Based Learning, Hidrokarbon

\section{PENDAHULUAN}

Pendidikan telah menjadi kebutuhan pokok untuk meningkatkan dan mengembangkan potensi sumber daya manusia. Pendidikan merupakan proses interaksi yang mendorong terjadinya proses belajar. Melalui pendidikan diharapkan dapat mengembangkan potensi peserta didik sehingga mampu menjadi sumber daya manusia yang lebih berkualitas. Didalam undang-undang nomor 20 tahun 2003 tentang sistem pendidikan nasional menyebutkan bahwa kurikulum adalah seperangkat rencana dan pengaturan mengenai tujuan, isi dan bahan pelajaran serta cara yang digunakan sebagai pedoman penyelenggaraan kegiatan pembelajaran untuk mencapai tujuan pendidikan tertentu. Untuk memperbaiki kualitas pendidikan, pemerintah juga turut berupaya dalam menyempurnakan kurikulum 2013 (Tania \& Susilowibowo, 2017).

Proses pembelajaran pada kurikulum 2013 untuk semua jenjang dilaksanakan dengan menggunakan pendekatan saintifik yaitu pendekatan pembelajaran yang berpusat pada peserta didik dimana kemampuan peserta didik diarahkan untuk mengetahui, memahami, menerapkan, menganalisis dan mengevaluasi. Tujuan pembelajaran sesuai pendekatan saintifik yaitu untuk mengembangkan keterampilan berpikir dan rasa ingin tahu peserta didik, sehingga peserta didik termotivasi untuk mengamati fenomena sekitarnya. Dalam memotivasi peserta didik, dilakukan dengan memvariasikan sumber belajar atau alat pembelajaran. Salah satunya dapat memanfaatkan kemajuan perkembangan teknologi informasi dan komunikasi (TIK). Kurikulum 2013 mengharapkan pembelajaran saintifik yang dilakukan dapat membantu peserta didik untuk terampil dalam menggunakan media teknologi informasi dan komunikasi (TIK) yang dibutuhkan pada abad 21 (Asmiyunda, Guspatni, \& Azra, 2018).

Salah satu pemanfaatan perkembangan TIK guna meningkatkan minat belajar peserta didik yaitu e-modul. E-modul merupakan suatu bahan ajar mandiri 
Al-Ishlah: Jurnal Pendidikan - ISSN: 2087-949o (p); 2597-940X (e)

Vol. 12, No. 2(2020)

yang memuat informasi dalam format digital, e-modul dapat memudahkan penggunanya. E-modul adalah hasil inovasi dari modul yang berbasis TIK yang memiliki kelebihan dibandingkan dengan modul cetak yakni adanya audio, video, gambar, animasi serta adanya tes kuis yang memberikan umpan balik bagi peserta didik (Cheva \& Zainul, 2019).

Keunggulan lain e-modul dalam proses pembelajaran terletak pada tahapan pembelajaran berdasarkan masalah, yaitu orientasi peserta didik kepada masalah, mengorganisasikan peserta didik untuk belajar, membimbing penyelidikan individual maupun kelompok, mengembangkan dan menyajikan hasil karya serta menganalisis dan mengevaluasi proses pemecahan masalah (Sugihartini \& Jayanta, 2017).

Pengembangan e-modul dapat dipadukan dengan model pembelajaran yang dipandang mampu menunjang aktivitas peserta didik, e-modul berbasis Problem Based Learning (PBL) yang merupakan metode instruksional yang menantang peserta didik agar belajar untuk belajar, bekerja sama dalam kelompok untuk mencari solusi, untuk meningkatkan rasa ingin tahu, kemampuan analisis dan inisiatif. Semakin banyak pengalaman peserta didik yang mendapatkan pembelajaran berorientasi PBL akan semakin meningkatkan keterampilan berpikir dan membangun pemikiran supaya lebih efektif digunakan dalam penyelesaian masalah (Alfiantara, Kusumo, \& Susilaningsih, 2016).

E-modul berbasis PBL menyediakan sumber belajar yang inovatif bagi peserta didik, sehingga pembelajaran lebih efektif, menarik dan membuat peserta didik belajar secara aktif untuk mencapai tujuan pembelajaran (Jaenudin, Baedhowi, \& Murwaningsih, 2017). Hal ini sesuai dengan penelitian yang dilakukan oleh (Serevina, Sunaryo, Raihanati, Astra, \& Sari, 2018) menyatakan bahwa e-modul berbasis PBL pada materi panas dan temperatur layak untuk digunakan dan e-modul tersebut dapat meningkatkan kemampuan proses sains dengan kategori sedang. Begitu pula penelitian yang dilakukan (UZ, Haryono, \& Wardani, 2019) menyatakan e-modul berbasis PBL pada materi koloid layak untuk digunakan dalam pembelajaran dan e-modul tersebut dapat meningkatkan pemahaman konsep peserta didik.

Materi yang dipilih pada penelitian ini adalah hidrokarbon. Hidrokarbon merupakan materi kimia yang tinggi tingkat keabstrakannya karena berkenaan dengan wujud, sifat dan reaksi-reaksi yang tak kasat mata sehingga dibutuhkan waktu yang lama untuk mempelajarinya (Iswandari, Copriady, Noer, \& Albeta, 2020). Materi hidrokarbon dianggap sulit dan membutuhkan pemahaman konsep yang kuat dan bersifat komprehensif, dalam materi hidrokarbon peserta didik dituntut untuk dapat mengenal hidrokarbon, mengetahui tata nama, isomer, sifatsifat, reaksi-reaksi serta kegunaan hidrokarbon dalam kehidupan sehari-hari (Septryanesti \& Lazulva, 2019). Berdasarkan hal tersebut maka dibutuhkan bahan 
Al-Ishlah: Jurnal Pendidikan - ISSN: 2087-949o (p); 2597-940X (e)

Vol. 12, No. 2(2020)

ajar yang dapat memudahkan peserta didik untuk menguasi dan memahami materi hidrokarbon. Dengan bantuan penggunaan e-modul yang menyajikan sebuah pembelajaran dengan menggabungkan teks, gambar dan video yang dapat menampilkan contoh-contoh senyawa hidrokarbon serta dilengkapi dengan rangkuman materi yang bisa digunakan peserta didik untuk memahami materi senyawa hidrokarbon serta soal-soal latihan yang fungsinya untuk mengevaluasi kemampuan peserta didik dalam penguasaan materi yang telah dipelajari (Nalarita \& Listiawan, 2018).

Berdasarkan hasil wawancara peneliti dengan guru kimia di SMAN 8 Pekanbaru, SMAN 5 Pekanbaru, SMAN 3 Pekanbaru dan SMAIT Al-Fityah Pekanbaru pada proses pembelajaran belum pernah menggunakan modul ataupun e-modul, yang biasa digunakan adalah buku cetak, dan tidak pernah dipadukannya suatu model pembelajaran seperti Problem Based Learning (PBL) dalam suatu bahan ajar. Berdasarkan hal tersebut peneliti tertarik mengembangkan e-modul hidrokarbon menggunakan aplikasi kvisoft flipbook maker.

Aplikasi kvisoft flipbook maker merupakan salah satu aplikasi yang tidak terpaku hanya pada tulisan-tulisan saja tetapi bisa dimasukkan sebuah animasi gerak, video dan audio yang bisa menjadi interaktif dan menarik sehingga pembelajaran tidak monoton. E-modul dengan menggunakan aplikasi kvisoft flipbook maker dapat diakses secara offline dan tidak harus mengeluarkan banyak biaya karena berbentuk soft file (Wibowo \& Pratiwi, 2018). Sebagaimana hasil penelitian yang dilakukan oleh (Fonda \& Sumargiyani, 2018) menyatakan emodul dengan pendekatan saintifik menggunakan kvisoft flipbook maker pro layak untuk digunakan dalam proses pembelajaran di kelas XI SMA. Begitu pula penelitian yang dilakukan (Andani \& Yulian, 2018) menyatakan bahwa e-book menggunakan software kvisoft flipbook pada materi hukum dasar kimia layak untuk digunakan sebagai bahan ajar di SMAN 1 Panton Reu Aceh Barat.

Penelitian yang dilakukan adalah penelitian pengembangan dengan menggunakan model pengembangan 4-D. Hasil penelitian ini berisi tentang kevalidan dan kepraktisan e-modul hidrokarbon berbasis Problem Based Learning (PBL) yang dikembangkan menggunakan aplikasi kvisoft flipbook maker. Sejauh penelusuran pustaka, penelitian ini belum pernah dilaporkan. Penelitian terdahulu telah mengembangkan e-modul berbasis Problem Based Learning (PBL) tetapi tidak menggunakan aplikasi kvisoft flipbook maker dan pada materi yang berbeda yaitu koloid (UZ, Haryono, \& Wardani, 2019). Penelitian pengembangan ini bertujuan untuk mengembangkan produk e-modul hidrokarbon berbasis Problem Based Learning (PBL) menggunakan aplikasi kvisoft flipbook maker.

\section{METODE PENELITIAN}

Penelitian ini merupakan penelitian pengembangan dengan menggunakan model pengembangan 4-D. Model pengembangan 4-D terdiri atas 4 tahap utama, 
Al-Ishlah: Jurnal Pendidikan - ISSN: 2087-9490 (p); 2597-940X (e)

Vol. 12, No. 2(2020)

yaitu: Define, Design, Develop dan Disseminate. Namun dalam penelitian ini peneliti hanya melakukan sampai tahap ketiga yaitu tahap Develop. Penelitian ini berfokus pada pengembangan e-modul hidrokarbon berbasis Problem Based Learning (PBL) menggunakan aplikasi kvisoft flipbook maker.

Penelitian ini dilaksanakan pada bulan Mei tahun ajaran 2019/2020 sampai dengan bulan Agustus tahun ajaran 2020/2021. Penelitian ini dilaksanakan di Universitas Riau, Universitas Islam Negeri Sultan Syarif Kasim Riau, Universitas Muhammadiyah Riau, SMAN 8 Pekanbaru, SMAN 5 Pekanbaru, SMAN 3 Pekanbaru dan SMAIT Al-Fityah Pekanbaru. Subjek penelitian yaitu 6 orang validator yang terdiri dari 3 orang ahli materi dan 3 orang ahli media yang merupakan Dosen Universitas Riau, Dosen Universitas Islam Negeri Sultan Syarif Kasim Riau dan Dosen Universitas Muhammadiyah Riau, serta pengguna yang terdiri dari 4 orang guru kimia dan 12 orang peserta didik SMAN 8 Pekanbaru, SMAN 5 Pekanbaru, SMAN 3 Pekanbaru dan SMAIT Al-Fityah Pekanbaru. Sedangkan objek penelitian ini adalah e-modul hidrokarbon berbasis Problem Based Learning (PBL) menggunakan aplikasi kvisoft flipbook maker.

Teknik pengumpulan data pada penelitian ini adalah dengan wawancara, dokumentasi dan angket. Angket yang digunakan disusun berdasarkan skala likert diantaranya berupa angket uji validitas oleh ahli materi dan ahli media, angket uji praktikalitas oleh guru dan peserta didik.

Tabel 1 Skala Angket Penelitian

\begin{tabular}{cc}
\hline Skor & Keterangan \\
\hline 5 & Sangat baik \\
4 & Baik \\
3 & Cukup baik \\
2 & Kurang baik \\
1 & Tidak baik \\
\hline
\end{tabular}

Data pengisian angket yang diperoleh pada penelitian ini diolah dengan analisis statistik deskriptif. Tingkat kelayakan atau kevalidan dan kepraktisan produk didapatkan dengan perhitungan persentase menggunakan rumus berikut: (Riduwan, 2014)

$$
\text { Persentase }=\frac{\text { jumlah skor hasil penilaian }}{\text { skor tertinggi }} \times 100 \%
$$

Data hasil penilaian yang telah diketahui persentasenya dideskripsikan dan diambil kesimpulan tentang masing-masing aspek penilaian. Untuk memudahkan membaca hasil penelitian, tabel interval persentase dapat digambarkan sebagai berikut yang mana tabel ini diadaptasi dan dimodifikasi dari (Riduwan, 2014): 
Al-Ishlah: Jurnal Pendidikan - ISSN: 2087-949o (p); 2597-940X (e)

Vol. 12, No. 2(2020)

Tabel 2 Persentase Tingkat Kevalidan Produk

\begin{tabular}{cc}
\hline Persentase Pencapaian & Interpretasi \\
\hline $81 \%-100 \%$ & Sangat valid \\
$61 \%-80 \%$ & Valid \\
$41 \%-60 \%$ & Cukup valid \\
$21 \%-40 \%$ & Tidak valid \\
$0 \%-20 \%$ & Sangat tidak valid \\
\hline
\end{tabular}

Tabel 3 Persentase Tingkat Kepraktisan Produk

\begin{tabular}{cc}
\hline Persentase Pencapaian & Interpretasi \\
\hline $81 \%-100 \%$ & Sangat praktis \\
$61 \%-80 \%$ & Praktis \\
$41 \%-60 \%$ & Cukup praktis \\
$21 \%-40 \%$ & Tidak praktis \\
$0 \%-20 \%$ & Sangat tidak praktis \\
\hline
\end{tabular}

\section{HASIL DAN PEMBAHASAN}

\section{Tahap Define}

Tahap ini dilakukan dengan wawancara terhadap guru kimia di SMAN 8 Pekanbaru, SMAN 5 Pekanbaru, SMAN 3 Pekanbaru dan SMAIT Al-Fityah Pekanbaru. Berdasarkan hasil wawancara dengan guru kimia diperoleh data bahwa belum tersedianya bahan ajar elektronik berupa e-modul dalam proses pembelajaran materi hidrokarbon. Bahan ajar yang digunakan yaitu buku teks yang dijual di pasaran. Hasil analisis peneliti buku teks tersebut belum menunjukkan pembelajaran abad 21 yang mengharuskan peserta didik untuk dapat mengembangkan kemampuan berpikir kritis, pemecahan masalah, komunikasi, kolaborasi dan kreativitas.

Hidrokarbon merupakan materi kimia kelas XI SMA/MA yang berkenaan dengan struktur molekul dan reaksi-reaksi yang bersifat abstrak sehingga dibutuhkan waktu yang lama untuk mempelajarinya, sementara alokasi waktu pembelajaran di sekolah terbatas sehingga dibutuhkan bahan ajar yang dapat digunakan kapan dan dimana saja (Iswandari, Copriady, Noer, \& Albeta, 2020). E-modul hidrokarbon berbasis Problem Based Learning (PBL) yang dibuat dengan menggunakan aplikasi kvisoft flipbook maker dapat digunakan kapan dan dimana saja serta bersifat interaktif yang dapat menampilkan gambar, audio, video dan animasi. Sehingga dengan keunggulan e-modul ini materi kimia khususnya hidrokarbon yang bersifat abstrak dapat dikuasai dengan baik oleh peserta didik.

\section{Tahap Design}

Tahap ini dilakukan dengan penyusunan tes berupa pembuatan angket untuk menilai kevalidan dan kepraktisan produk, pemilihan media yang digunakan dalam proses pembuatan e-modul antaranya microsoft publisher, chemsketch dan kvisoft flipbook maker, pemilihan format dilakukan dengan mengumpulkan bahan-bahan pendukung dalam pembuatan e-modul antaranya 
Al-Ishlah: Jurnal Pendidikan - ISSN: 2087-949o (p); 2597-940X (e)

Vol. 12, No. 2(2020)

buku, gambar dan video yang berkaitan dengan materi hidrokarbon dan yang terakhir adalah perancangan awal atau pembuatan produk e-modul.

E-modul yang telah dirancang terdiri dari cover, kata pengantar, daftar isi, glosarium, pendahuluan: KD dan IPK, deskripsi, waktu, prasyarat dan petunjuk penggunaan e-modul, kegiatan pembelajaran: tujuan, uraian materi, rangkuman, tugas, latihan dan penilaian diri, evaluasi, kunci jawaban, daftar pustaka dan lampiran (SMA, 2017). E-modul hidrokarbon berbasis Problem Based Learning (PBL) ini dikembangkan dengan mengikuti sintak model pembelajaran PBL antaranya orientasi peserta didik pada masalah, mengorganisasikan peserta didik untuk belajar, membimbing penyelidikan individu maupun kelompok, mengembangkan dan menyajikan hasil karya serta menganalisis dan mengevaluasi proses pemecahan masalah (Ariana, Pudjiastuti, Bestary, \& Zamroni, 2019). Sintak PBL yang terdapat pada e-modul dapat dijabarkan sebagai berikut: langkah pertama yaitu orientasi masalah maka terdapat bahan bacaan di dalam e-modul yang dapat diamati atau dipahami pengguna untuk menemukan suatu masalah, langkah kedua yaitu organisasi belajar maka terdapat materi dalam e-modul sebagai bahan untuk menyelesaikan masalah dalam belajar, langkah ketiga yaitu penyelidikan maka terdapat contoh soal yang dapat membantu pengguna melakukan penyelidikan, langkah keempat yaitu menyajikan hasil penyelidikan maka terdapat cara penyelesaian contoh soal yang dapat membantu pengguna untuk menyajikan hasil penyelidikan dan langkah terakhir yaitu menganalisis dan mengevaluasi proses penyelidikan maka terdapat jawaban contoh soal dan rangkuman yang dapat dijadikan bahan analisis dan evaluasi proses penyelidikan.

E-modul ini dibuat menggunakan aplikasi kvisoft flipbook maker. Aplikasi kvisoft flipbook maker merupakan aplikasi yang membantu dalam proses pembelajaran karena aplikasi ini tidak terpaku hanya pada tulisan-tulisan saja tetapi bisa dimasukan sebuah animasi gerak, video, dan audio yang bisa menjadikannya interaktif sehingga pembelajaran menjadi tidak monoton. E-modul dengan menggunakan aplikasi kvisoft flipbook maker dapat di akses secara offline dan tidak harus mengeluarkan banyak biaya karena berbentuk soft file (Wibowo \& Pratiwi, 2018).

\section{Tahap Develop}

Tujuan dari tahap ini adalah untuk menghasilkan e-modul hidrokarbon berbasis Problem Based Learning (PBL) yang sudah direvisi berdasarkan saran atau masukan dari beberapa validator dan di uji cobakan ke SMAN 8 Pekanbaru, SMAN 5 Pekanbaru, SMAN 3 Pekanbaru dan SMAIT Al-Fityah Pekanbaru untuk menentukan tingkat kepraktisannya. Tahap ini terdiri dari beberapa kegiatan antaranya: uji validitas, revisi dan uji praktikalitas. 
Al-Ishlah: Jurnal Pendidikan - ISSN: 2087-949o (p); 2597-940X (e)

Vol. 12, No. 2(2020)

Uji validitas bertujuan untuk melihat tingkat validitas dari e-modul yang dikembangkan. Uji validitas dilakukan oleh 6 orang validator antaranya 3 orang ahli materi untuk menilai aspek isi, aspek penyajian, aspek bahasa, dan aspek Problem Based Learning (PBL) dan 3 orang ahli media untuk menilai aspek kegrafikan dan aspek pemrograman. E-modul hidrokarbon berbasis Problem Based Learning (PBL) yang telah dinilai memiliki persentase $85,39 \%$ oleh ahli materi dan 97,02\% oleh ahli media dengan kategori sangat valid. Hasil pengolahan data penilaian angket validitas e-modul hidrokarbon berbasis Problem Based Learning (PBL) oleh ahli materi dapat dilihat pada Grafik 1.

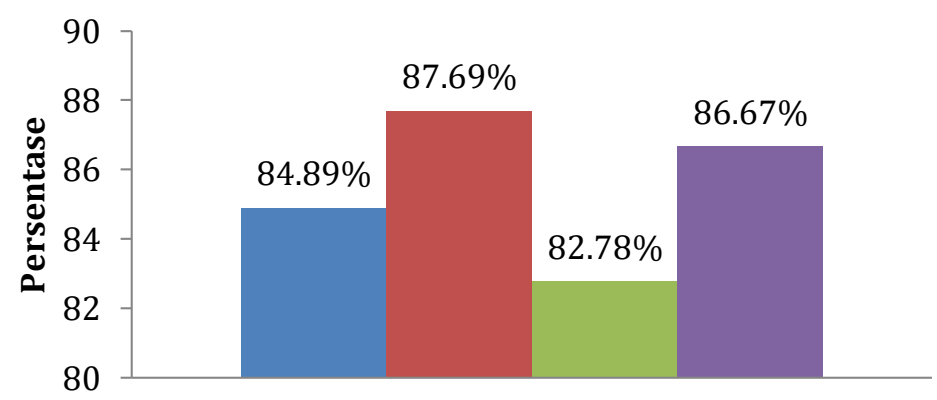

aspek Isi $\square$ Aspek Penyajian $\square$ Aspek Bahasa $\square$ Aspek PBL

\section{Grafik 1 Persentase Uji Validitas Ahli Materi}

Aspek isi memiliki persentase $84,89 \%$ dengan kategori sangat valid. Ini berarti bahwa e-modul yang dikembangkan telah sesuai dengan tuntutan kompetensi dasar pada silabus kurikulum 2013 revisi 2017. E-modul yang baik dapat dihasilkan apabila e-modul telah sesuai dengan kompetensi dasar. E-modul yang dikembangkan memuat kesesuaian antara soal-soal yang diberikan dengan materi yang dipelajari, tampilan gambar dan video yang dapat memberikan informasi dan membantu peserta didik dalam memahami materi hidrokarbon. Aspek penyajian memiliki persentase $87,69 \%$ dengan kategori sangat valid. Hal ini berarti bahwa e-modul yang dikembangkan telah sesuai dengan indikator dan tujuan pembelajaran yang harus dicapai (Sari, Z, \& Guspatni, 2018). Penyajian emodul sudah sistematik mengikuti kerangka e-modul yang disusun pada (SMA, 2017) terdiri dari cover, kata pengantar, daftar isi, glosarium, pendahuluan: KD dan IPK, deskripsi, waktu, prasyarat dan petunjuk penggunaan e-modul, kegiatan pembelajaran: tujuan, uraian materi, rangkuman, tugas, latihan dan penilaian diri, evaluasi, kunci jawaban, daftar pustaka dan lampiran.

Aspek isi memiliki persentase 82,78\% dengan kategori sangat valid. Hal ini menunjukkan bahwa bahasa yang digunakan dalam e-modul telah sesuai dengan kaidah bahasa Indonesia sehingga informasi yang diberikan mudah dipahami peserta didik dan tidak menimbulkan kerancuan. Sesuai dengan Depdiknas bahwa akan dihasilkan suatu bahan ajar yang baik apabila dilakukan 
Al-Ishlah: Jurnal Pendidikan - ISSN: 2087-949o (p); 2597-940X (e)

Vol. 12, No. 2(2020)

evaluasi terhadap aspek-aspek didalamnya yakni keterbacaan, kejelasan informasi, kesesuaian dengan kaidah bahasa Indonesia yang baik dan benar serta penggunaan bahasa yang jelas dan mudah untuk dipahami (Sari, Z, \& Guspatni, 2018). Aspek Problem Based Learning (PBL) memiliki persentase 86,67\% dengan kategori sangat valid. Hal ini menunjukkan bahwa e-modul hidrokarbon berbasis PBL ini telah disusun berdasarkan sintak model pembelajaran PBL. E-modul yang dikembangkan mengarahkan penggunanya untuk menyelesaikan masalah yang diberikan diawal dengan memberikan bahan bacaan dan soal-soal mengenai materi ajar sehingga membuat peserta didik mencapai tujuan pembelajaran yang diharapkan. Hasil pengolahan data penilaian angket validitas e-modul hidrokarbon berbasis PBL oleh ahli media dapat dilihat pada Grafik 2.

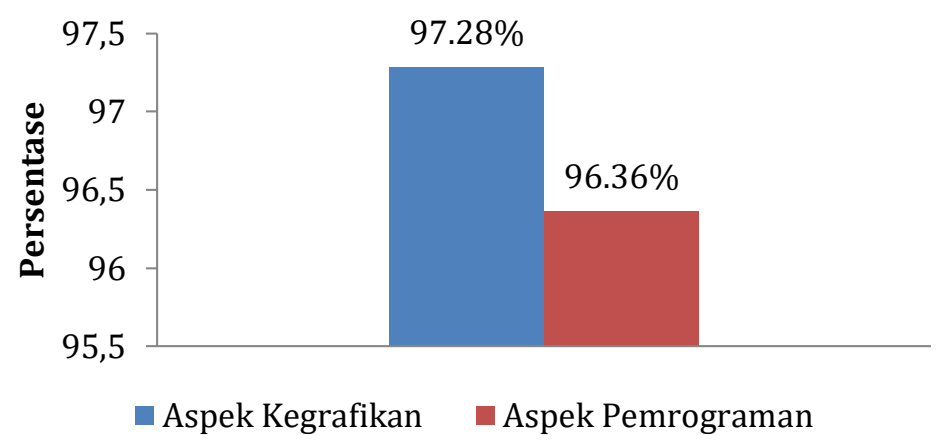

\section{Grafik 2 Persentase Uji Validitas Ahli Media}

Aspek kegrafikan memiliki persentase 97,28\% dengan kategori sangat valid. Hal ini menunjukkan bahwa e-modul yang dikembangkan telah menggunakan jenis dan ukuran huruf yang jelas terbaca, tampilan cover dan tata letak isi e-modul yang menarik, gambar dan video yang disajikan dapat diamati dengan jelas sehingga dapat dipahami dengan baik untuk memecahkan masalah dalam proses pembelajaran. Hal ini sesuai juga dengan karakteristik e-modul yaitu penggunaan font, spasi dan tata letak yang konsisten (Asmiyunda, Guspatni, \& Azra, 2018). Aspek pemrograman memiliki persentase 96,36\% dengan kategori sangat valid. Hal ini menunjukkan bahwa e-modul yang dikembangkan dapat digunakan dengan mudah oleh pengguna sehingga dapat digunakan kapan dan dimana saja.

Revisi dilakukan dengan tujuan untuk memperbaiki bagian e-modul hidrokarbon berbasis Problem Based Learning (PBL) sesuai dengan saran yang diberikan oleh validator. Perbaikan dan saran dari validator terhadap e-modul yang dikembangkan dapat dilihat pada Tabel 4. 
Al-Ishlah: Jurnal Pendidikan - ISSN: 2087-949o (p); 2597-940X (e)

Vol. 12, No. 2(2020)

Tabel 4 Perbaikan dan Saran Validator

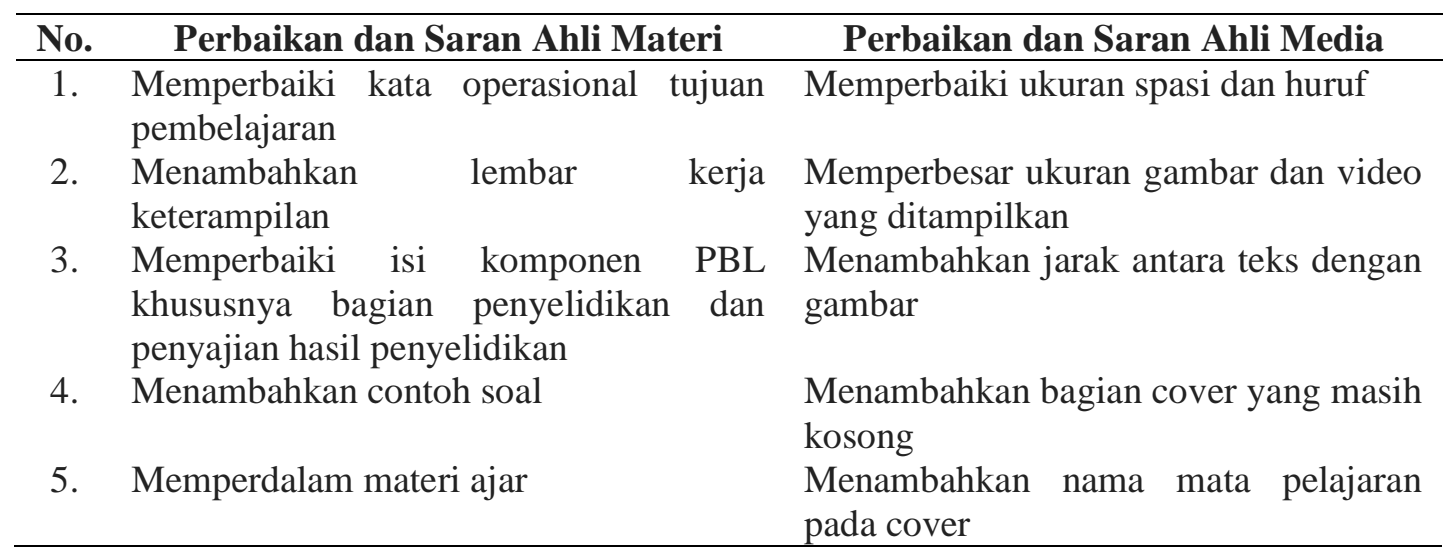

Uji praktikalitas diperoleh dari hasil angket respon 4 orang guru kimia dan angket respon 12 orang peserta didik untuk menilai aspek kemudahan penggunaan, aspek efisiensi waktu pembelajaran dan aspek manfaat. Penilaian uji praktikalitas oleh guru kimia memiliki persentase 92,60\% dengan kategori sangat praktis dan penilaian oleh peserta didik memiliki persentase $89,60 \%$ dengan kategori sangat praktis. Hasil analisis data respon guru kimia dapat dilihat pada Grafik 3 dan hasil analisis data respon peserta didik dapat dilihat pada Grafik 4.

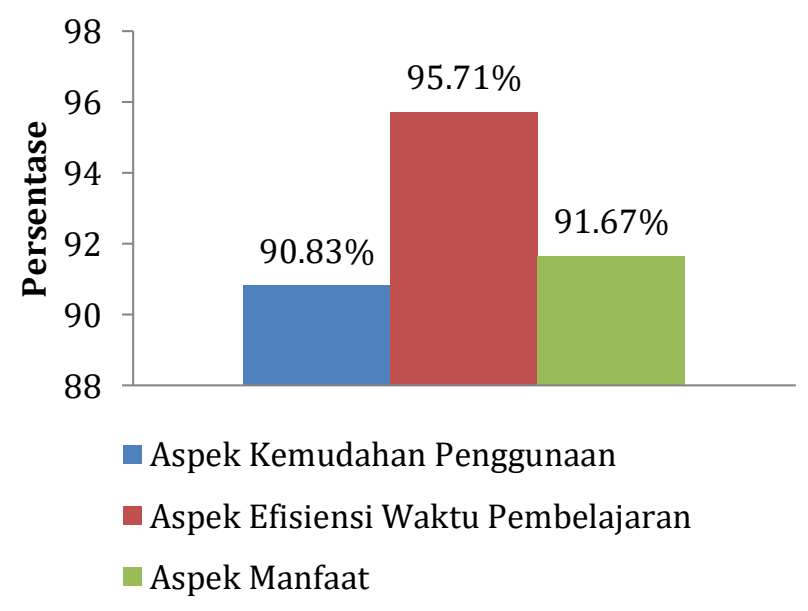

Grafik 3 Persentase Uji Praktikalitas Guru Kimia 
Al-Ishlah: Jurnal Pendidikan - ISSN: 2087-949o (p); 2597-940X (e)

Vol. 12, No. 2(2020)

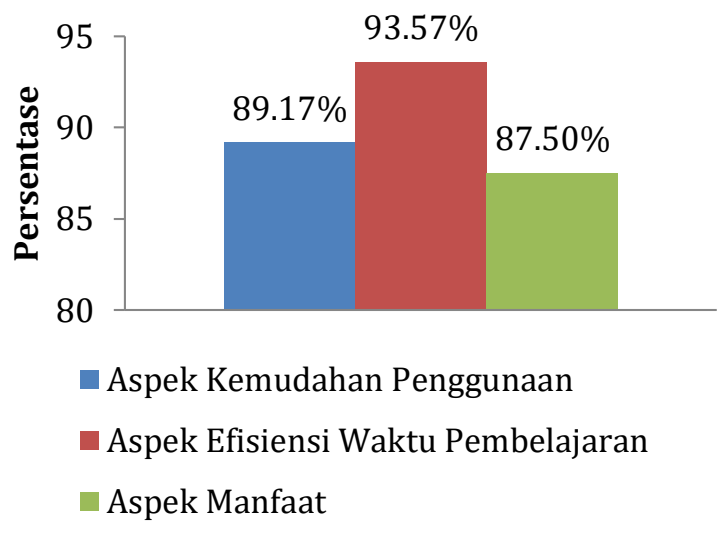

\section{Grafik 4 Persentase Uji Praktikalitas Peserta Didik}

Persentase aspek kemudahan penggunaan dari penilaian guru kimia dan peserta didik secara berturut-turut adalah $90,83 \%$ dan $89,17 \%$ yang memiliki kategori sangat praktis. Hal ini menunjukkan bahwa petunjuk penggunaan emodul yang dikembangkan mudah dipahami, materi yang disajikan jelas, langkahlangkah kegiatan pembelajaran pada e-modul jelas dan mudah dipahami, isi emodul mudah dipahami karena menggunakan huruf yang mudah dibaca, e-modul mudah digunakan atau dioperasikan, dapat digunakan berulang-ulang serta mudah dibawa karena berbentuk softfile. Persentase aspek efisiensi waktu pembelajaran dari penilaian guru kimia dan peserta didik secara berturut-turut adalah 95,71\% dan $93,57 \%$ yang memiliki kategori sangat praktis. Hal ini menunjukkan bahwa emodul dapat membantu peserta didik belajar sesuai kecepatannya dan dengan menggunakan e-modul ini waktu pembelajaran menjadi lebih efisien. Sesuai dengan (Hamdani, 2011) bahwa tujuan penggunaan bahan ajar salah satunya adalah untuk memudahkan guru dalam menyampaikan materi ajar sehingga waktu pembelajaran menjadi lebih efisien.

Persentase aspek manfaat dari penilaian guru kimia dan peserta didik secara berturut-turut adalah $91,67 \%$ dan $87,50 \%$ yang memiliki kategori sangat praktis. Hal ini menunjukkan bahwa e-modul yang dikembangkan telah membantu peserta didik untuk belajar mandiri. Penggunaan e-modul juga dapat meningkatkan rasa ingin tahu peserta didik terhadap materi yang dipelajari sehingga tercipta suasana belajar yang menyenangkan. Langkah-langkah yang disajikan dalam e-modul jelas, sistematis dan mudah dipahami oleh peserta didik serta dapat membantu peran guru sebagai fasilitator. Hal ini menjadikan guru tidak perlu menjelaskan semua materi karena peserta didik lebih berperan aktif dalam proses pembelajaran sehingga pembelajaran berpusat pada peserta didik. 
Al-Ishlah: Jurnal Pendidikan - ISSN: 2087-949o (p); 2597-940X (e)

Vol. 12, No. 2(2020)

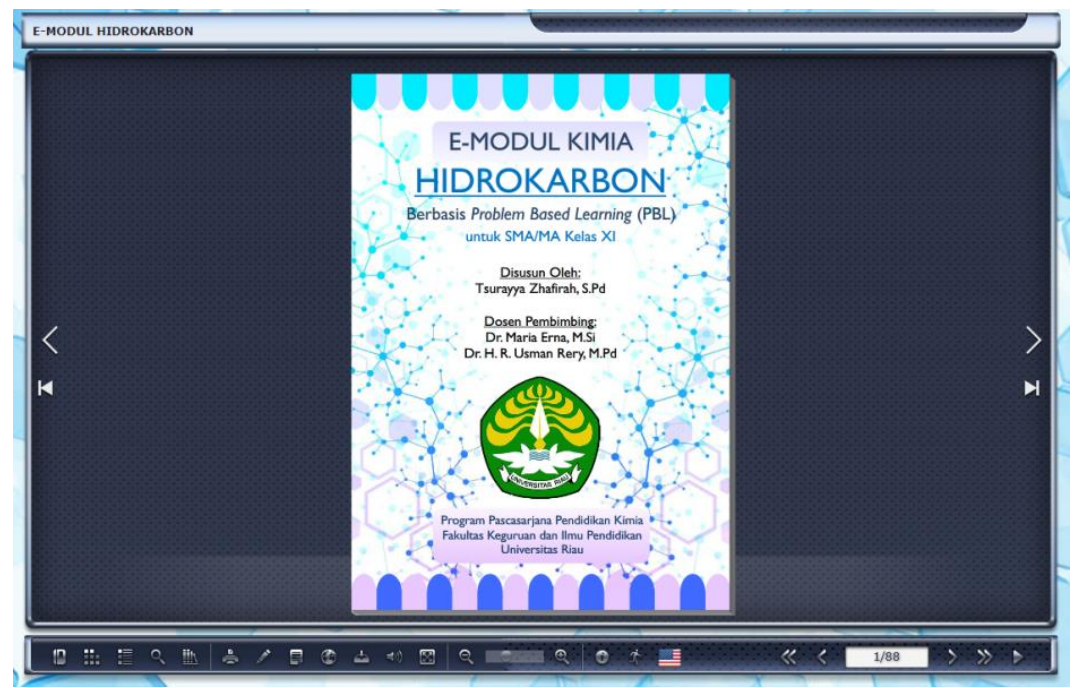

Gambar 1 Cover Depan E-Modul

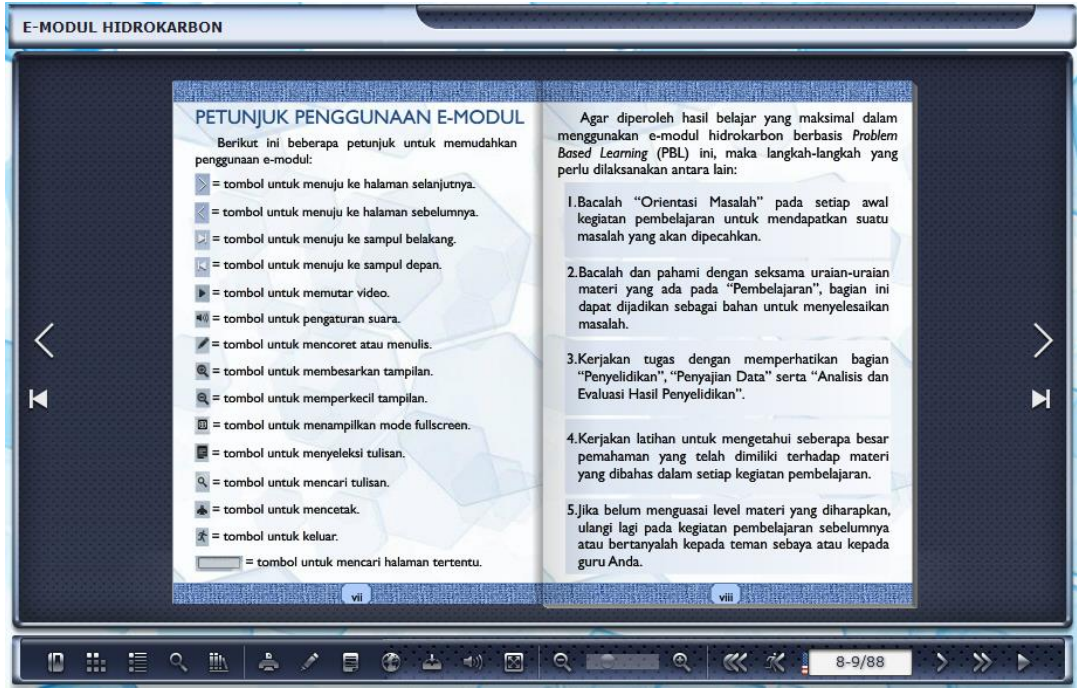

Gambar 2 Petunjuk Penggunaan E-Modul

\section{SIMPULAN}

Berdasarkan hasil penelitian dan pengolahan data maka dapat disimpulkan bahwa e-modul hidrokarbon berbasis Problem Based Learning (PBL) telah dapat dikembangkan dengan model pengembangan 4-D. E-modul yang dikembangkan memiliki tingkat kevalidan yang sangat valid dengan persentase $85,39 \%$ oleh ahli materi dan 97,02\% oleh ahli media. Hasil angket respon terhadap penggunaan produk yang dikembangkan memiliki tingkat kepraktisan yang sangat praktis berdasarkan penilaian dari guru kimia dan peserta didik dengan persentase secara berurutan adalah $92,60 \%$ dan $89,60 \%$. Bagi peneliti selanjutnya untuk dapat melakukan uji efektivitas e-modul yang telah dikembangkan. 
Al-Ishlah: Jurnal Pendidikan - ISSN: 2087-949o (p); 2597-940X (e)

Vol. 12, No. 2(2020)

\section{DAFTAR PUSTAKA}

Alfiantara, A., Kusumo, E., \& Susilaningsih, E. (2016). Pengembangan E-Modul Berorientasi Problem Based Learning Berbantuan Aplikasi Android. Jurnal Inovasi Pendidikan Kimia, 1769-1777.

Andani, D. T., \& Yulian, M. (2018). Pengembangan Bahan Ajar Electronic Book Menggunakan Software Kvisoft Flipbook Pada Materi Hukum Dasar Kimia di SMA Negeri 1 Panton Reu Aceh Barat. Jurnal IPA dan Pembelajaran IPA, 1-6.

Ariana, Y., Pudjiastuti, A., Bestary, R., \& Zamroni. (2019). Buku Pegangan Pembelajaran Berorientasi pada Keterampilan Berpikir Tingkat Tinggi. Jakarta: Ditjen Guru dan Tenaga Kependidikan.

Asmiyunda, Guspatni, \& Azra, F. (2018). Pengembangan E-Modul Keseimbangan Kimia Berbasis Pendekatan Saintifik untuk Kelas XI SMA/MA. Jurnal Eksakta Pendidikan, 155-161.

Cheva, V. K., \& Zainul, R. (2019). Pengembangan E-Modul Berbasis Inkuiri Terbimbing pada Materi Sifat Keperiodikan Unsur untuk SMA/MA Kelas X. Jurnal Edukimia, 28-36.

Fonda, A., \& Sumargiyani. (2018). The Developing Math Electronic Module With Scientific Approach Using Kvisoft Flipbook Maker Pro For XI Grade of Senior High School. Journal of Mathematics Education , 109122.

Hamdani. (2011). Strategi Belajar Mengajar. Bandung: Pustaka Setia.

Iswandari, S. N., Copriady, J., Noer, A. M., \& Albeta, S. W. (2020). Pengembangan E-Modul Berbasis Moodle pada Materi Hidrokarbon. Jurnal Edusains, 81-88.

Jaenudin, A., Baedhowi, \& Murwaningsih, T. (2017). The Effectiveness of the EModule of Economics Learning on Problem Based Learning used to Improve Students Learning Outcomes. Education and Humanities Research (ASSEHR), 30-36.

Nalarita, Y., \& Listiawan, T. (2018). Pengembangan E-Modul Kontekstual Interaktif Berbasis Web pada Mata Pelajaran Kimia Senyawa Hidrokarbon. Jurnal Multitek Indonesia, 85-94.

Riduwan. (2014). Dasar-Dasar Statistika. Bandung: Alfabeta.

Sari, S. D., Z, R., \& Guspatni. (2018). Pengembangan E-Modul Berbasis Pendekatan Saintifik pada Materi Hidrolisis Garam untuk Siswa Kelas XI SMA/MA. Journal of Residu, 139-146. 
Al-Ishlah: Jurnal Pendidikan - ISSN: 2087-949o (p); 2597-940X (e)

Vol. 12, No. 2(2020)

Septryanesti, N., \& Lazulva. (2019). Desain dan Uji Coba E-Modul Pembelajaran Kimia Berbasis Blog pada Materi Hidrokarbon. Jurnal Tadris Kimiya, 202-215.

Serevina, V., Sunaryo, Raihanati, Astra, I. M., \& Sari, I. J. (2018). Development of E-Module Based on Problem Based Learning (PBL) on Heat and Temperature to Improve Student's Science Process Skill. The Turkish Online Journal of Educational Technology, 26-36.

SMA, D. P. (2017). Panduan Praktis Penyusunan E-Modul. Jakarta: Ditjen Pendidikan Dasar dan Menengah.

Sugihartini, N., \& Jayanta, N. L. (2017). Pengembangan E-Modul Mata Kuliah Strategi Pembelajaran. Jurnal Pendidikan Teknologi dan Kejuruan, 221230.

Tania, L., \& Susilowibowo, J. (2017). Pengembangan Bahan Ajar E-Modul sebagai Pendukung Pembelajaran Kurikulum 2013 pada Materi Ayat Jurnal Penyesuaian Perusahaan Jasa Siswa Kelas X Akuntansi SMK Negeri 1 Surabaya. Jurnal Pendidikan Akuntansi, 1-9.

UZ, L. Z., Haryono, \& Wardani, S. (2019). The Development of Chemical EModule Based on Problem of Learning to Improve The Concept of Student Understanding. Innovative Journal of Curriculum and Educational Technology, 59-66.

Wibowo, E., \& Pratiwi, D. D. (2018). Pengembangan Bahan Ajar Menggunakan Aplikasi Kvisoft Flipbook Maker Materi Himpunan. Jurnal Matematika, 147-156. 